University of Wollongong

Research Online

Faculty of Engineering and Information

Faculty of Engineering and Information

Sciences - Papers: Part B

Sciences

2018

Axial Load-Axial Deformation Behaviour of SCC Columns Reinforced with Steel Tubes

Faez Alhussainy

University of Wollongong, fama867@uowmail.edu.au

M Neaz Sheikh

University of Wollongong, msheikh@uow.edu.au

Muhammad N. S Hadi

University of Wollongong, mhadi@uow.edu.au

Follow this and additional works at: https://ro.uow.edu.au/eispapers1

Part of the Engineering Commons, and the Science and Technology Studies Commons

Research Online is the open access institutional repository for the University of Wollongong. For further information contact the UOW Library: research-pubs@uow.edu.au 


\title{
Axial Load-Axial Deformation Behaviour of SCC Columns Reinforced with Steel Tubes
}

\author{
Abstract \\ A simplified analytical model has been developed for the axial load-axial deformation behaviour of self- \\ compacting concrete (SCC) columns reinforced with steel tubes. The developed analytical model takes \\ into account the contribution of the steel tubes, unconfined concrete cover, confined concrete core and \\ confined concrete inside the steel tube. The results of the analytical model have been compared with \\ experimental results of four SCC column specimens. The results of the analytical model are in good \\ agreement with the experimental results. A parametric study has been conducted to investigate the \\ influences of the compressive strength of SCC, tensile strength of steel tube, wall thickness of steel tube \\ and pitch of steel helix on the axial load-axial deformation behaviour of SCC columns reinforced with \\ steel tubes. The ductility of SCC columns has been found to be significantly influenced by the increase in \\ the compressive strength of SCC and the pitch of steel helix.

\section{Disciplines} \\ Engineering | Science and Technology Studies

\section{Publication Details} \\ Alhussainy, F., Sheikh, M. Neaz. \& Hadi, M. N. S. (2018). Axial Load-Axial Deformation Behaviour of SCC \\ Columns Reinforced with Steel Tubes. Structures, 15 259-269.
}




\section{Accepted Manuscript}

Axial Load-Axial Deformation Behaviour of SCC Columns Reinforced with Steel Tubes

Faez Alhussainy, M. Neaz Sheikh, Muhammad N.S. Hadi

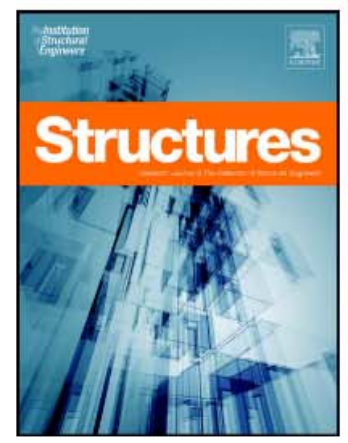

PII:

S2352-0124(18)30070-5

DOI: doi:10.1016/j.istruc.2018.07.006

Reference: ISTRUC 300

To appear in: Structures

Received date: 16 March 2018

Revised date:

19 June 2018

Accepted date:

15 July 2018

Please cite this article as: Faez Alhussainy, M. Neaz Sheikh, Muhammad N.S. Hadi, Axial Load-Axial Deformation Behaviour of SCC Columns Reinforced with Steel Tubes. Istruc (2018), doi:10.1016/j.istruc.2018.07.006

This is a PDF file of an unedited manuscript that has been accepted for publication. As a service to our customers we are providing this early version of the manuscript. The manuscript will undergo copyediting, typesetting, and review of the resulting proof before it is published in its final form. Please note that during the production process errors may be discovered which could affect the content, and all legal disclaimers that apply to the journal pertain. 


\title{
Axial Load-Axial Deformation Behaviour of SCC Columns Reinforced with
}

\section{Steel Tubes}

\author{
Faez Alhussainy ${ }^{1}$
}

${ }^{1}$ Ph.D. Candidate, School of Civil, Mining, and Environmental Engineering,

\author{
University of Wollongong, Australia. \\ Email: fama867@uowmail.edu.au \\ M. Neaz Sheikh² \\ ${ }^{2}$ Associate Professor, School of Civil, Mining, and Envirommental Engineering, \\ University of Wollongong, Australia. \\ Email: $\underline{\text { msheikh@uow.edu.au }}$ \\ Muhammad N. S. Hadi ${ }^{3, *}$ (Fellow of ASCE) \\ ${ }^{3}$ Associate Professor, School of Civil, Mining, and Environmental Engineering, \\ University of Wollongong, Australia. \\ Email: mhadi@uow.edu.au, \\ ${ }^{*}$ Corresponding author
}

\begin{abstract}
A simplified analytical model has been developed for the axial load-axial deformation behaviour of self-compacting concrete (SCC) columns reinforced with steel tubes. The developed analytical model takes into account the contribution of the steel tubes, unconfined concrete cover, confined concrete core and confined concrete inside the steel tube. The results of the analytical model have been compared with experimental results of four SCC column specimens. The results of the analytical model are in good agreement with the experimental results. A parametric study has been conducted to investigate the influences of the compressive strength of SCC, tensile strength of steel tube, wall thickness of steel tube and
\end{abstract}


pitch of steel helix on the axial load-axial deformation behaviour of SCC columns reinforced with steel tubes. The ductility of SCC columns has been found to be significantly influenced by the increase in the compressive strength of SCC and the pitch of steel helix.

Keywords: Composite columns; self-compacting concrete; steel tube; axial load-axial deformation; ductility.

\section{Introduction}

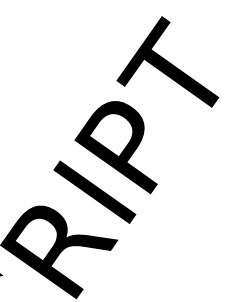

Steel sections and concrete are commonly used in the c nstryction of composite columns. There are two main configurations of the composite corms: concrete-encased steel section columns and concrete-filled steel tube (CFT) [1]. The advantages of composite columns are high strength, stiffness, ductilit fire-resistance and seismic resistance $[2,3]$. Steel tubes with different cross-sections (retalar, square, polygon and circular) are used to construct CFT columns $[4,5]$. Circtar steel tube sections are usually preferred for the CFT columns because circular steel tyeg provide better confinement to the infill concrete [6]. In traditional CFT columns, steef tokes are usually filled with concrete without any internal steel reinforcement [7]. In some Cses, internal steel reinforcement is used for higher strengths and better connections beween concrete members [8].

Reinforced con (RC) columns are usually constructed of normal-vibrated concrete (NVC). However, the congestion of reinforcement in the construction of columns is a critical issue. Casting concrete in columns with a large amount of longitudinal and transverse reinforcements makes the placement of concrete difficult. For such columns, the selfcompacting concrete (SCC) is considered a suitable option to overcome the difficulty of the placement of concrete because SCC possesses good workability with high flowability, passing 
ability and segregation resistances [9]. The SCC can be easily poured into narrow, complex or novel forms of construction without requiring vibration even in columns containing a large amount of reinforcement $[10,11]$.

Lin et al. [12] examined the behaviour of axially loaded RC columns constructed of NVC and SCC. Test results showed that the ductility, stiffness and crack copsol ability of the SCC columns were better than NVC columns. Lachemi et al. [13] ex hed the performance of axially loaded CFT columns constructed of NVC and SCC. TNescries of steel tube confined concrete columns with and without longitudinal and trarere reinforcement were tested. The test results showed that axial load carrying capacites ofNVC columns and SCC columns were comparable. Also, the casting of columns was easier than casting of columns with NVC, as SCC did not require any vibrati Recently, the authors proposed a method of reinforcing SCC columns with small
diameter steel tubes as longituding rentercement [14]. The behaviour of SCC columns
reinforced with steel tubes is arferent from the behaviour of SCC columns reinforced with conventional steel bars. Fon same cross-sectional area, the radius of gyration of the steel tube is higher than trads of gyration of the solid steel bar. Steel tubes filled with SCC decreased the ov rall guckling of longitudinal reinforcement and consequently increased the ductility of the columns. Also, steel tubes effectively confined the infill concrete resulting in an increase of the axial compressive strength. Under concentric axial load, steel tubes with a tensile strength similar to that of steel bars used in reinforcing SCC columns increased the maximum axial load of the column [14]. However, no analytical investigations have yet been carried out for the influence of different parameters (e.g., the compressive 
strength of SCC, tensile strength of steel tube, wall thickness of steel tube and pitch of steel helix) on the behaviour of SCC columns reinforced with steel tubes.

Detailed analytical investigations are required for the wide use of SCC columns reinforced with steel tubes. This paper develops an analytical model to predict the axial load-axial deformation behaviour of SCC columns reinforced with steel tub. The results of the analytical model have been found well matching with the experin a tal investigation results. The influences of the compressive strength of SCC, tens etrength of steel tube, wall thickness of steel tube and pitch of steel helix on the axia loat-axial deformation behaviour of SCC columns reinforced with steel tubes have been gated.

\section{Research significance}

This study presents a simplified analytid model for the axial load-axial deformation behaviour of SCC columns reinforge with steel tubes. The analytical model takes into account the contributions of the stabes, unconfined concrete cover, confined concrete core and confined concrete instict the steel tube. The predictions of the developed analytical model have been found to in good agreement with the experimental investigation results. The analytical obsery ations based on a detailed parametric study, reported in this study will contribute to go understanding on the axial load-axial deformation behaviour of SCC columns reinforcgarvith steel tubes.

\section{Analytical modelling}

The authors have recently proposed using small diameter steel tubes as longitudinal reinforcement for SCC columns. The innovative use of steel tubes for reinforcing SCC column was found to be highly effective, especially considering the maximum axial load and 
the ductility of the SCC columns [14]. The conventional SCC columns reinforced with steel bars usually consist of three main components: Iongitudinal steel bars, unconfined concrete cover and confined concrete core (Fig. 1a). The SCC columns reinforced with steel tubes consist of four main components: longitudinal steel tubes, unconfined concrete cover, confined concrete core and confined concrete inside the steel tubes (Fig. 1b).

\subsection{Modelling of longitudinal steel tubes}

A simplified stress-strain relationship is used in the analytica of the longitudinal steel tubes. The stress-strain behaviour of the steel tubes uder tension and compression is idealized as bilinear elasto-plastic (Equations 1a and whe strain hardening response of the longitudinal steel tube was neglected for a simplifad andical model.

$$
\begin{aligned}
& f_{t}=\varepsilon_{t} E_{t} \\
& f_{t}=f_{t y}
\end{aligned}
$$

where $f_{t}$ is the stress of the steel tube is the axial strain corresponding to the $f_{t}, f_{t y}$ is the yield stress of the steel tube, $\varepsilon_{t y}$ and $E_{t}$ is the modulus of elasticity of the ctel tarbe.

3.2 Modelling of und fnfing concrete cover
The stress-strain Gehayiour of self-compacting concrete (SCC) in Aslani and Nejadi [15] is
adopted to modthe stress-strain behaviour of unconfined concrete cover in the SCC column. The stress-strain behaviour (Equation 2) of the SCC in Aslani and Nejadi [15] is divided into two branches: ascending (Equation 3a) and descending (Equation 3b).

$$
\begin{gathered}
f_{c}=\frac{f_{c o} n\left(\varepsilon_{c} / \varepsilon_{c o}\right)}{n-1+\left(\varepsilon_{c} / \varepsilon_{c o}\right)^{n}} \\
n=n_{1}=\left[1.02-1.17\left(E_{s e c, u} / E_{c}\right)\right]^{-0.74} \text { if } \varepsilon_{c} \leq \varepsilon_{c o}
\end{gathered}
$$




$$
\begin{gathered}
n=n_{2}=n 1+(\varpi+28 \times \xi) \quad \text { if } \varepsilon_{c}>\varepsilon_{c o} \\
E_{c}=3655 \times\left(f_{c o}\right)^{0.548 \quad(\mathrm{MPa})} \\
\varpi=\left(135.16-0.1744 \times f_{c o}\right)^{-0.46} \\
\xi=0.83 \exp \left(-911 / f_{c o}\right) \\
E_{s e c, u}=\frac{f_{c o}}{\varepsilon_{c o}} \\
\varepsilon_{c o}=\left(\frac{f_{c o}}{E_{c}}\right)\left(\frac{\psi}{\psi-1}\right) \\
\psi=\left(\frac{f_{c o}}{17}\right)+0.8
\end{gathered}
$$

where $\varepsilon_{c}$ is the axial strain at any unconfined concrete stres $f_{c i} f_{c o}$ is the unconfined concrete compressive strength; $\varepsilon_{c o}$ is the axial strain corresondig to $f_{c o} ; E_{c}$ is the modulus of elasticity of SCC (with fly ash filler); $E_{s e c, u}$ is the seant modulus of elasticity of unconfined concrete; $n$ is the material parameter dependif shape of the stress-strain curve; $n_{1}$ and $n_{2}$ are the modified material parame ascending and descending branches, respectively; and $\varpi, \xi$ and $\psi$ are coefroments of equations expressed in term of $f_{c o}$.

The unconfined concrete compressive strength $f_{c o}$ is considered equal to 28-day cylinder compressive strength (mastiplied by a coefficient $\propto_{1}$ according to AS 3600 [16]. The coefficient $\alpha_{1}$ is exp essed as:

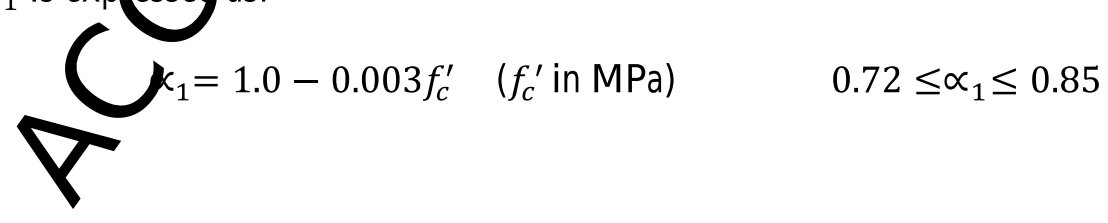

\subsection{Modelling of confined concrete}

Two confined concrete models need to be used in the modelling SCC columns reinforced with longitudinal steel tubes for the stress-strain behaviour of confined concrete core and confined concrete inside the steel tubes. The concrete stress-strain model in Mander et al. [17] is adopted to model the stress-strain behaviour of confined concrete core (Equation 11). 


$$
\begin{gathered}
f_{c c}=\frac{f_{c c}^{\prime} r_{c}\left(\varepsilon_{c c} / \varepsilon_{c c}^{\prime}\right)}{r_{c}-1+\left(\varepsilon_{c c} / \varepsilon_{c c}^{\prime}\right)^{r_{c}}} \\
r_{c}=\frac{E_{c}}{E_{c}-E_{s e c, c}} \\
E_{s e c, c}=\frac{f_{c c}^{\prime}}{\varepsilon_{c c}^{\prime}}
\end{gathered}
$$

where $\varepsilon_{c c}$ is the axial strain in concrete at any confined concrete stress $f_{c c}, \varepsilon_{c c}^{\prime}$ is the axial strain at the peak stress of confined concrete $f_{c c}^{\prime}$, and $E_{s e c, c}$ is the seant modulus of elasticity of the confined concrete. The $f_{c c}^{\prime}$ and $\varepsilon_{c c}^{\prime}$ are calculated using Equations (14) and (15), respectively.

$$
\begin{gathered}
f_{c c}^{\prime}=f_{c o}\left(2.254 \times \sqrt{1+\frac{7.94 f_{l}}{f_{c o}}}-\frac{2 f_{l}}{f_{c o}}-1.254\right) \\
\varepsilon_{c c}^{\prime}=\varepsilon_{c o}\left[1+5\left(\frac{f_{c c}^{\prime}}{f_{c o}}-1\right)\right]
\end{gathered}
$$

The ultimate confined concrete compressive strength in Mander et al. [17] is usually used with normal strength concrete having a compressive strength ranging between 27 and 31 $\mathrm{MPa}$. However, for concrete with the compressive strengths higher than $31 \mathrm{MPa}$, Bing et al. [18] adjusted the peak stress of confined concrete $f_{c c}^{\prime}$ with a modification factor $\alpha_{s}$ (Equation 16), which has been adopted herein.

$$
\begin{array}{ll}
f_{c c}^{\prime}=f_{c o}\left(2.254 \times \sqrt{1+\frac{7.94 \alpha_{s} f_{l}}{f_{c o}}}-\frac{2 \alpha_{s} f_{l}}{f_{c o}}-1.254\right) \\
\alpha_{s}=\left(21.2-0.35 f_{c o}\right) \frac{f_{l}}{f_{c o}} \quad \text { when } f_{c o} \leq 52 \mathrm{MPa} \\
\alpha_{s}=3.1 \frac{f_{l}}{f_{c o}} \quad \text { when } f_{c o}>52 \mathrm{MPa}
\end{array}
$$

where $f_{l}$ is the effective confining pressure of the steel helix, which is calculated as:

$$
\begin{gathered}
f_{l}=\frac{1}{2} k_{e} \rho_{s h} f_{y h} \\
\rho_{s h}=\frac{4 A_{s h}}{s D_{c}}
\end{gathered}
$$




$$
k_{e}=\frac{1-\frac{s^{\prime}}{2 D_{c}}}{1-\rho_{c c}}
$$

where $f_{y h}$ is the yield stress of steel helix, $\rho_{s h}$ is the volumetric ratio of steel helix, $A_{s h}$ is the area of steel helix, $D_{c}$ is the centre-to-centre diameter of steel helix, $k_{e}$ is the coefficient of the fully confined concrete core by steel helix, $\rho_{c c}$ is the ratio of longitudinal steel area to the concrete core area, $s$ is the centre-to-centre spacing (pitch) of steel bix and $s^{\prime}$ is the clear spacing between the turns of steel helix.

The concrete stress-strain behaviour in Mander et al. [17] 5 alsg adopted to model the stressstrain behaviour of confined SCC inside the steel turowever, the effective confining pressure provided by the steel tube is different frame ffective confining pressure provided by the steel helix. The steel helix mainly provianconfining pressure to the concrete core, whereas the steel tube resists axial stres addition to providing confinement to the concrete inside the steel tube. The common assumption adopted for the maximum confining pressure is that the steel helix wiy the yield stress [17]. This assumption may not be pressure provided by the tube is calculated based on the equilibrium of forces using Equation (22).

$$
f_{l t}=\frac{2 \sigma_{\theta} t}{d_{t}-2 t}
$$

where $\sigma_{\theta}$ is the bop stress of the steel tube, $d_{t}$ is the outside diameter of the steel tube, and $t$ is the wall thickness of the steel tube. It is noted that a similar equation is also used for CFT columns [19]. However, the hoop stress of the steel tube in SCC columns reinforced with steel tubes is different from the hoop stress of the CFT columns because steel tubes in SCC columns reinforced with steel tubes are subjected to the restraining effect provided by the 
concrete around the steel tube. The hoop stress of the steel tube in the SCC column reinforced with steel tubes is calculated as:

$$
\sigma_{\theta}=\varepsilon_{\theta} E_{t}
$$

where $\varepsilon_{\theta}$ is the hoop strain of the steel tube and $E_{t}$ is the modulus of elasticity of the steel tube.

A hoop strain factor $\left(\alpha_{\theta}\right)$ has been defined herein as:

$$
\alpha_{\theta}=\sigma_{\theta} / f_{t y}
$$

The $\alpha_{\theta}$ of the CFT columns ranged 0.10 to $0.19[20,21]$. Pever, the $\alpha_{\theta}$ of steel tube in SCC columns reinforced with steel tubes is higher than th of the CFT columns. This is because additional confining pressures are provided the seel tube by the steel helix and the concrete around the steel tube in SCC columns reinferced with steel tubes.

\subsection{Analytical axial load-axial deformati-niour}

The axial load-axial deformation response of SCC columns reinforced with steel tubes is calculated based on the develop tress-strain responses of the SCC and steel tubes. For an axial strain, the stress in each component (longitudinal steel tubes, unconfined concrete cover, confined concrete core 3 nfined concrete inside the steel tubes) is calculated (Fig. 2a). The axial deformation of the specimen is calculated by multiplying the considered axial strains with the total length of the specimen. The axial load contribution of each component is calculated by nuplying the stresses of each component with the respective cross-sectional area (Fig. 2b). The steel helices essentially influence the stress-strain behaviour of the confined concrete core. The steel helices also influence the hoop strain of the longitudinal steel tubes. The influence of the pitch of steel helices is accounted for in the confined SCC inside the steel tubes. The effective confining pressure $\left(f_{l t}\right)$ provided by the steel tube is calculated based on the experimentally determined hoop strain (average strains of strain 
gauges at the maximum axial load) of the steel tube $\left(\varepsilon_{\theta}\right)$. The total axial load of the SCC columns reinforced with steel tubes is calculated as:

$$
P_{\text {axial }}=f_{t} A_{t}+f_{c, \text { cover }} A_{\text {cover }}+f_{c c, \text { core }} A_{\text {core }}+f_{c c, t u b e} A_{\text {tube }}
$$

where $P_{\text {axial }}$ is the total axial load of specimens; $f_{t}, f_{c, \text { cover }}, f_{c c, \text { core }}$ and $f_{c c, \text { tube }}$ are the axial stresses in the longitudinal steel tubes, unconfined concrete cover, confined concrete core and confined concrete inside steel tubes, respectively; $A_{t}, A_{\text {cover }}, A_{\text {core }} A_{\text {tube }}$ are the crosssectional areas of longitudinal steel tubes, unconfined concrete con confined concrete core and confined concrete inside steel tubes, respectively.

\section{Experimental axial load-axial deformation behaviour}

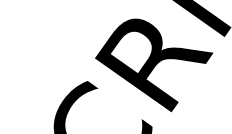

A total of four SCC column specimens reinforced witnsteel tubes were cast and tested under monotonic axial compression. All specime tested at the Structural Engineering Laboratories, School of Civil, Mining Environmental Engineering, University of Wollongong, Australia. The details or the experimental program including the design of experiments, preparation and tering failure modes and behaviour of the specimens under concentric, eccentric and flexurar wads were presented in Hadi et al. [14].

4.1 Details of the col amn specimens

All specimens w re $240 \mathrm{~mm}$ in diameter and $800 \mathrm{~mm}$ in height. The SCC mix with a nominal compressive stergth of $50 \mathrm{MPa}$ and a maximum aggregate size of $10 \mathrm{~mm}$ were used in casting the specimens. The first and second specimens were reinforced longitudinally with ST33.7 steel tubes. The ST33.7 steel tube had $33.7 \mathrm{~mm}$ outside diameter, $2 \mathrm{~mm}$ wall thickness and $350 \mathrm{MPa}$ nominal tensile strength. The first and second specimens were reinforced transversely with $50 \mathrm{~mm}$ and $75 \mathrm{~mm}$ pitch of the steel helices, respectively. The third and fourth specimens were reinforced longitudinally with ST26.9 steel tubes. The ST26.9 steel 
tube had $26.9 \mathrm{~mm}$ outside diameter, $2.6 \mathrm{~mm}$ wall thickness and $250 \mathrm{MPa}$ nominal tensile strength. The third and fourth specimens were also reinforced transversely with $50 \mathrm{~mm}$ and 75 $\mathrm{mm}$ pitch of the steel helices, respectively. Both ST33.7 and ST26.9 steel tubes had approximately the same cross-sectional area. All specimens were reinforced transversely with R10 bar (10 mm diameter plain steel bar) with a nominal tensile strength of $250 \mathrm{MPa}$.

The SCC column specimens were labelled according to the typplongitudinal steel tubes and the pitch of the steel helix (Table 1). In the specimen la the type of the steel tubes. Afterwards, H50 and H75 repre ent $50 \mathrm{~mm}$ and $75 \mathrm{~mm}$ pitch of the steel helices, respectively. The letter $C$ at the end of Suecimen label represents that the specimen was tested under concentric axial loadexample, ST26.9H50C refers to the column specimen reinforced longitudinally with $\mathbf{2} 26.9$ steel tubes and transversely with 50 $\mathrm{mm}$ pitch of the steel helix and tested undercentric axial load. Table 1 provides details of the column specimens included in thicstydy.

\subsection{Materials properties}

The properties of fresh selempacting concrete (SCC) were tested according to ASTM C1621/C1621M [22/ASM C1611/C1611M [23] and ASTM C1610/C1610M [24]. The compressive stre of the SCC was determined by testing three cylinders of $100 \mathrm{~mm}$ diameter and 0 mm height according to ASTM C39/C39M [25]. The average 28-day compressive strength of the SCC was $57 \mathrm{MPa}$. Two different steel tubes were used for steel tube reinforced SCC specimens: ST33.7 and ST26.9. Three samples from each of ST33.7 and ST26.9 tubes were tested according to ASTM A370 [26]. Yield stresses of both steel tubes were determined using the $0.2 \%$ offset method, as clearly defined yield stress was not observed. The average yield stress $\left(f_{t y}\right)$, yield strain $\left(\varepsilon_{t y}\right)$ and modulus of elasticity $\left(E_{t}\right)$ of 
ST33.7 steel tube were found as $450 \mathrm{MPa}, 0.23 \%$ and $196 \mathrm{GPa}$, respectively. The average yield stress, yield strain and modulus of elasticity of ST26.9 steel tube were found as 355 $\mathrm{MPa}, 0.187 \%$ and $192 \mathrm{GPa}$, respectively.

Rounded steel R10 helices were used as transverse reinforcement in all of the specimens. Three samples of R10 rounded steel bars (gauge length $340 \mathrm{~mm}$ ) tested according to Australian Standard AS 1391 [27]. The yield stress of rounded stee par was determined using the $0.2 \%$ offset method, as clearly defined yield stress was at abserved. The average yield stress $\left(f_{y h}\right)$, yield strain $\left(\varepsilon_{y h}\right)$ and modulus of elasticity $\left(E_{h}\right)$ R10 bars were found as 400 $\mathrm{MPa}, 0.22 \%$ and $195 \mathrm{GPa}$, respectively.

\subsection{Instrumentation}

The test specimens were instrumented integrolly and externally to measure the strains of reinforcements (steel tubes and steel fetices) and axial deformations of specimens. In order to observe the axial strains of long unina steel tubes, strain gauges were attached on the two opposite longitudinal steel turs. Also, to observe the lateral strains of transverse reinforcement, two straingauses were attached to the two opposite sides of the steel helices. All strain gauges were antached to the external faces of the longitudinal and transverse reinforcements a the pidheight of the specimens. Two types of strain gauges were used in this study: singeferement strain gauges were used for steel helices and biaxial two element strain gauges were used for steel tubes. Biaxial two element strain gauges were used to measure both the axial and the lateral strains of the longitudinal steel tube. The biaxial two element strain gauges were placed at the mid-height of the steel tubes ensuring that they were centrally placed between two turns of the helix. Figure 3 shows the schematic of the positions of single element strain gauges and biaxial two element strain gauges on the test specimens. 
The test specimens were instrumented with two linear variable differential transducers (LVDTs) fixed diagonally at opposite corners in the testing machine to measure the axial deformations. All specimens were tested in a $5000 \mathrm{kN}$ compression testing machine. Testing was carried out at a displacement controlled loading rate of $0.3 \mathrm{~mm} / \mathrm{min}$ until the failure of the specimen.

\section{Experimental results of the SCC column specimens}

Experimental results of four SCC column specimens tested ander concentric axial load in terms of yield axial load and corresponding axial defor natign, maximum axial load and corresponding axial deformation and ultimate axial deforman are presented in Table 1. The ultimate axial deformation corresponds to the defommetion at the fracture of steel helices. Although the cross-sectional areas of the ST327 and ST26.9 steel tubes are similar, the yield axial load of Specimen ST33.7H50C was yogreater than the yield axial load of Specimen ST26.9H50C and the maximum axiartagd of Specimen ST33.7H50C was $4.8 \%$ greater than the maximum axial load of Specimen $3 \mathrm{~T} 26.9 \mathrm{H} 50 \mathrm{C}$. The greater yield and maximum axial load of specimen reinforced 1 ST33.7 steel tubes were because the ST33.7 steel tube had higher tensile strength tban ST26.9 steel tube. Besides, the ST33.7 steel tube had large inside and outside dirmete compared to the ST26.9 steel tube. The large inside diameter of the ST33.7 steel ube allowed a large amount of concrete to be filled inside the tube which contributed in vereasing the compressive strength of the column specimens. The large outside diameter of ST33.7 steel tube had a lower slenderness $\left(s / d_{t}\right)$ ratio which positively contributed to the maximum axial load of Specimen ST33.7H50C.

Table 2 reports the strains in the longitudinal and transverse reinforcements for all tested specimens. In Column 1 of Table 2, the letters SA, SL and SH refer to the strain gauges that 
were placed on the steel tubes in the longitudinal direction, on the steel tubes in the lateral direction and on the steel helix in the lateral direction, respectively. The numbers 1 and 2 afterwards refer to the first and second strain gauges, respectively. The averages of the recorded strains are also reported in Table 2 . The average axial strains in the longitudinal steel tubes indicated that the steel tubes yielded at the maximum axial load. Also, it was found that the contribution of ST33.7 steel tubes was $29.8 \%$ of the maximum/xial load of Specimen ST33.7H50C, whereas the contribution of ST33.7 steel tubes whe maximum axial load of Specimen ST33.7H75C. The contribution of S $2 \%$-steel tubes was $30.7 \%$ of the maximum axial load of Specimen ST26.9H50C, wher as th contribution of ST26.9 steel tubes was $24.5 \%$ of the maximum axial load of Speciuren $5126.9 \mathrm{H} 75 \mathrm{C}$. The maximum axial load of steel tubes filled with concrete decreased increase in the $s / d_{t}$ ratio of steel tubes $[11,28]$. Thus, increasing $s / d_{t}$ rathe steel tubes resulted in the lower contributions of steel tubes in the maximum load of the tested column specimen.

The compressive strength of the confined concrete core and the compressive strength of the confined concrete inside the the have been compared. It has been observed that steel tubes effectively confiped concrete inside the tube and resulted in higher axial compressive strengt/s of the SCC columns. To compare the compressive strength of the confined concret corg $\left(f_{c c, \text { core }}\right)$ and confined concrete inside the steel tube $\left(f_{c c, t u b e}\right)$, the enhancement ther of the confined concrete core $\left(f_{c c, c o r e} / f_{c o}\right)$ and the confined concrete inside the steel tube $\left(f_{c c, \text { tube }} / f_{c o}\right)$ were calculated based on the developed stress-strain behaviours of the SCC and steel tubes (Table 3). The unconfined concrete strength $\left(f_{c o}\right)$ is taken as 0.95 times the 28-day cylinder compressive strength for concrete inside the steel tubes [29]. For the concrete core confined by steel helix, the enhancement factors were 1.32 and 1.13 for the pitch of steel helices of 50 and $75 \mathrm{~mm}$, respectively. However, for the 


\section{ACCEPTED MANUSCRIPT}

confined concrete inside ST33.7 steel tube, the enhancement factors were 2.6 and 2.25 for the pitch of steel helices of 50 and $75 \mathrm{~mm}$, respectively. Also, for confined concrete inside the ST26.9 steel tube, the enhancement factors were 3.41 and 2.34 for the pitch of steel helices of 50 and $75 \mathrm{~mm}$, respectively. It can be observed that the enhancement factors of the confined concrete inside steel tubes were higher than the enhancement factors of the confined concrete core for the same pitch of steel helices. The enhancement factor is hig inside the steel tube, which is because the concrete inside the steel tube was effective Confined by the wall of steel tube as well as the steel helix and the concrete around th staltube.

The enhancement factor of confined concrete inside the 20.9 steel tube was $31 \%$ more than the enhancement factor of confined concrete insid n33.7 steel tube, when the pitch of steel helix was $50 \mathrm{~mm}$. The enhancement factor the concrete inside the steel tube was larger for smaller diameter steel tube, as the singth of confined concrete inside the steel tube increased with decreasing the diam of the steel tube [4]. Also, outside diameter to thickness $\left(d_{t} / t\right)$ ratio of the ST 269 seel tube was 10.35 , whereas the $d_{t} / t$ ratio of the ST33.7 steel tube was 16.85. Thower $d_{t} / t$ ratio of steel tube provided higher confinement to the concrete inside the sube [30]. The steel helix also provided confinement to the steel tubes in the CC Clumn. This additional confinement by steel helix resulted in restricting the lat ral djlation of the steel tube due to axial compression at the connecting area between the steprylix and steel tubes. Thus, the confinement of concrete inside steel tubes also decreases with the increase of the steel helix pitch.

\section{Analytical versus experimental results}

The analytical and experimental axial load-axial deformation behaviours of the SCC column specimens reinforced with steel tubes are compared (Fig. 4). For all the column specimens, 
for the ascending part of the curve up to the maximum axial load, the analytical axial loadaxial deformation curve correlated well with the experimental axial load-axial deformation curve. This good correlation is particularly because the stress-strain response of the different components of the specimens up to the maximum axial load was relatively linear. It can also be observed that, after the maximum axial load, the descending parts of the analytical axial load-axial deformation curves show good agreements with the expental axial load-axial deformation curves. The experimental axial load-axial deformation she shows a small drop and $a$ rise in the descending part of the curve. However thalytical axial load-axial deformation curve shows a gradual decrease in the desce ding part of the curve. The small drop in the experimental axial load-axial deformatione has not been captured by the analytical curve, as the drop occurred instantane to the spalling of concrete cover and then the axial load increased to a valuess than the maximum axial load due to the confinement provided by the steel helices

\section{Parametric study}

The developed analytical moderwas used to study the influences of different parameters on the axial load-axial deforman behaviours of SCC columns reinforced with steel tubes. The parameters studied yere thempressive strength of SCC, tensile strength of steel tube, wall thickness of steel ube and pitch of steel helix.

\subsection{Effect of concrete compressive strength}

Four different concrete compressive strengths $(30,40,50$ and $60 \mathrm{MPa})$ were considered. The SCC columns were reinforced longitudinally with either ST33.7 steel tube or ST26.9 steel tube and transversely with $50 \mathrm{~mm}$ pitch of steel helix. The tensile strengths of ST33.7 and 
ST26.9 steel tubes were $450 \mathrm{MPa}$ and $355 \mathrm{MPa}$, respectively, which were similar to the yield strength of the steel tubes used in reinforcing the tested column specimens.

The influence of concrete strength on the axial load-axial deformation behaviours of the SCC columns is shown in Fig. 5. As expected, the maximum axial load of the SCC columns reinforced with steel tubes increased with the increase in the conpressive strength of concrete. It was observed that as the concrete compressive strengt freased from $30 \mathrm{MPa}$ to $60 \mathrm{MPa}$, the maximum axial load of the columns reinforced tubes increased by about $27.7 \%$ and $30.5 \%$, respective ( $\mathrm{V}$ (Dable 4 ). This is particularly because increasing the strength of concrete increased 3 ntribution of the concrete to the maximum axial load of the column. Also, the maxim axial load of the steel tubes filled with concrete increased with increasing concentesthength [7]. For the descending part of the axial load-axial deformation response, the grope of the axial load-axial deformation curve after the maximum axial load ingsed with the increase in the concrete strength. Ozbakkaloglu and Saatcioglu [37 repoled that the reduction in the axial load capacity after the peak load was a function the concrete strength and the rate of drop in the axial load carrying capacity increased th increasing concrete strength.

The ductility of Columns was significantly influenced by the increase in the compressive strength of confres The ductility is an indication of the ability of the structural members to undergo large deformations before failure. In this study, the ductility was calculated as a ratio of the axial deformation at the first helix fracture $\left(\delta_{u}\right)$ to the axial yield deformation $\left(\delta_{y}\right)$ [32], as in Equation (26). The $\delta_{y}$ represents the deformation corresponding to the intersection point of a horizontal line from the maximum axial load and an extension secant line from the original point and the point at 0.75 times the maximum axial load [33]. 


$$
\text { Ductility }=\delta_{u} / \delta_{y}
$$

In this study, the analytical axial load-axial deformation curves matched well with the experimental axial load-axial deformation curves. Consequently, the ductility of the specimens obtained from the analytical investigations was very similar to the ductility of the specimens obtained from the experimental investigations. It was observed that as the compressive strength of concrete increased from $30 \mathrm{MPa}$ to $60 \mathrm{MPa}$, the ductility of Specimen ST33.7H50C decreased by about 19.4\%, whereas ductility of Specimen ST26.9H50C decreased by about 22.2\% (Table 4). For the in the compressive strength of concrete from $30 \mathrm{MPa}$ to $60 \mathrm{MPa}$, columns kinfliced with ST26.9 steel tubes showed a rapid descending axial load-axial deformation cye than columns reinforced with ST33.7 steel tubes. The $s / d_{t}$ ratio of Specimen SN. $450 \mathrm{C}$ was $20 \%$ higher than the $s / d_{t}$ ratio of Specimen ST33.7H50C, as the outsia the ST26.9 steel tube was smaller than the outside diameter of the ST33.7 Increasing $s / d_{t}$ ratio of columns caused an increase in the slope of the post peak axy load-axial deformation of the column (Fig. 5).

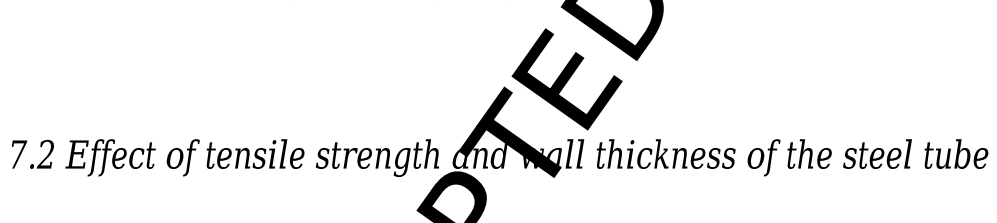

Steel tubes with four differentensile strengths $(300,400,500$ and $600 \mathrm{MPa})$ and with four different wall thickn (sses $1.5,2.0,2.5$ and $3.0 \mathrm{~mm}$ ) were considered. The SCC columns were reinforced longit dinaly with either ST33.7 steel tube or ST26.9 steel tube and transversely with $50 \mathrm{~mm}$ pit 50 steel helix. The compressive strength of the SCC was considered $57 \mathrm{MPa}$ which was similar to the compressive strength of the SCC used in casting the tested column specimens. The influence of tensile strength of steel tubes on axial load-axial deformation behaviours for the SCC columns is shown in Fig. 6. It was observed that the tensile strength of the steel tubes did not influence the overall trend of the axial load-axial deformation behaviour of the SCC columns. However, it was observed that as the tensile strength of 
longitudinal steel tubes increased from $300 \mathrm{MPa}$ to $600 \mathrm{MPa}$, the maximum axial load of Specimens ST33.7H50C and ST26.9H50C increased by about $15.7 \%$ and $14.7 \%$, respectively (Table 5). The higher strength of longitudinal steel tubes increased the contribution of steel tube in carrying the axial load of the column.

The influence of wall thicknesses of steel tubes on axial load-axial/aformation behaviours for the SCC columns is shown in Fig. 7. The thicknesses of steet did not significantly influence the overall trend of the axial load-axial deformat of columns. However, the maximum axial load of the SCC columns wa inceased with the increase in the wall thickness of steel tubes. It was observed that as wall thickness of steel tubes increased from $1.5 \mathrm{~mm}$ to $3.0 \mathrm{~mm}$, the maximuntoad of the columns reinforced with ST33.7 steel tubes increased by about 13. Whereas the maximum axial load of the columns reinforced with ST26.9 steel tubes foreased by about $8.4 \%$ (Table 6). The reason for the differences in the maximum axizhload is associated with the cross-sectional area of the steel tube. The cross-sectional ar af the ST33.7 steel tube was $28.4 \%$ larger than the crosssectional area of the ST26.9 tube, when the wall thickness of both steel tubes was considered $3 \mathrm{~mm}$. The highe wall thickness of steel tube increased the cross-sectional area of the steel tube and in rease the contribution of steel tube in carrying the axial load of the column. Also, in reasing the wall thickness of steel tube increased the compressive strength of the concrepside the steel tube and increased the compressive strength of the SCC column. The confinement of concrete inside the steel tube increased with decreasing $d_{t} / t$ ratio of the steel tube.

The increase in the tensile strength and wall thickness of steel tube increased the maximum axial load of the columns. However, the ductility of the SCC columns was not increased 
significantly. For the increase of the wall thickness of steel tubes in the SCC columns from $1.5 \mathrm{~mm}$ to $3.0 \mathrm{~mm}$, the ductility of the SCC columns reinforced with steel tubes increased by only $6 \%$ (Table 6). Although increasing the wall thickness of steel tube resulted in an increase in the strength and ductility of concrete inside the steel tubes, the concrete inside the steel tubes was a small proportion of the total cross-sectional area of the column.

\subsection{Effect of pitch of steel helices}

Four different pitches of steel helices $(40,60,80$ and 100 p. The SCC columns were reinforced longitudinally with either ST33 $\mathbf{Y}$ stel tube or ST26.9 steel tube. The tensile strengths of ST33.7 and ST26.9 steel (urves were $450 \mathrm{MPa}$ and $355 \mathrm{MPa}$, respectively. The compressive strength of the SCCwas MPa.

The influence of different pitch of steel helleson axial load-axial deformation behaviours of the SCC columns is shown in Fig. 8. columns showed the same initial behaviour up to the maximum axial load. However, for the ncrease of the pitch of steel helices from 40 to 100 $\mathrm{mm}$ in the SCC columns Rinirged with ST26.9 steel tubes, the maximum axial load decreased by $10.3 \%$ (Tahle Whereas increasing the pitch of steel helices from 40 to 100 $\mathrm{mm}$ in the SCC corumns reinforced with ST33.7 steel tubes, the maximum axial load decreased by $6.9 \%$ (Table 7). The reason for the differences in the maximum axial loads is associated withes $/ d_{t}$ ratio of steel tubes. The $s / d_{t}$ ratio of the ST26.9 steel tube was $25 \%$ higher than the $s / d_{t}$ ratio of the ST33.7 steel tube when the pitch of steel helix was $100 \mathrm{~mm}$.

It was observed that for increasing the pitch of steel helices from 40 to $100 \mathrm{~mm}$ in the SCC columns reinforced with ST26.9 steel tubes, the ductility decreased by $40 \%$ (Table 7). Whereas increasing the pitch of steel helices from 40 to $100 \mathrm{~mm}$ in the SCC columns 
reinforced with ST33.7 steel tubes, the ductility decreased by $37 \%$ (Table 7). The higher ductility of the column transversely reinforced with a smaller pitch steel helices is mainly attributed to the delay in the first helix fracture compared to the early first helix fracture of the column transversely reinforced with a larger pitch steel helices. Increasing the pitch of steel helices from 40 to $100 \mathrm{~mm}$ in the SCC columns resulted in the increase of the $s / d_{t}$ ratio of steel tubes. The ability of the column transversely reinforced with clofv spaced steel helix in sustaining the lateral pressure provided by the longitudina eel tubes under axial compression was higher than the ability of the column tran reaby reinforced with largely spaced steel helix. The lateral pressure exerted by the Ior fitudinal steel tubes in the largely spaced steel helix resulted in the early yielding and facturig of steel helix. Also, increasing the pitch of steel helices from 40 to $100 \mathrm{~mm}$ signifandy influenced the descending part of the axial load-axial deformation behaviour of column and resulted in an increase of the slope of the post-peak axial load-axid deformation curve (Fig. 8). It is noted that experimental investigations are required for very small and very large pitches of steel helices to verify the results of analytical ongoing research project by the authors.

\section{Conclusions}

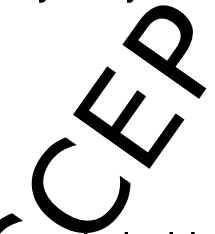

This study preser is anflytical investigations on the axial load-axial deformation behaviour of self-compactin gomcrete (SCC) columns reinforced with steel tubes. Two types of steel tubes were used in the SCC columns as longitudinal reinforcement. The influences of different parameters including the compressive strength of SCC, tensile strength of steel tube, wall thickness of steel tube and pitch of steel helix were investigated. Based on the analytical results of this study, the following conclusions are drawn: 
1. The analytical axial load-axial deformation response of the SCC columns reinforced with steel tubes was calculated based on the stress-strain responses of the longitudinal steel tubes, unconfined concrete cover, confined concrete core and confined concrete inside the steel tube. The analytical and experimental axial load-axial deformation curves of columns showed good agreements.

2. The compressive strength of the confined concrete core and the comprossive strength of the confined concrete inside the steel tube were compared. For the columns reinforced transversely with steel helices having a pitch of $50 \mathrm{~mm}$ enhancement factor of the confined concrete core was 1.32, whereas the enhancementartors of the confined concrete inside the ST33.7 and ST26.9 steel tubes were 2.6 and 3.41, respectively. The enhancement factors of the confined concrete inside the stenes were higher than the enhancement factors of the confined concrete core for the pitch of steel helices. Thus, steel tubes effectively confined the concrete inside tube and resulted in higher axial compressive strengths of the SCC columns.

3. As the concrete compressis strength increased from $30 \mathrm{MPa}$ to $60 \mathrm{MPa}$, the maximum axial load of the SCC col 1 seinforced with ST33.7 and ST26.9 steel tubes increased by about $27.7 \%$ and $30.5 \%$ spectively. With the increase in the compressive strength of concrete from $30 \mathrm{MPa} 57 \mathrm{MPa}$, the ductility of Specimen ST33.7H50C decreased by about $19.4 \%$, where the quctility of Specimen $\mathrm{ST} 26.9 \mathrm{H} 50 \mathrm{C}$ decreased by about $22.2 \%$.

4. As the tensile strength of longitudinal steel tubes increased from $300 \mathrm{MPa}$ to $600 \mathrm{MPa}$, the maximum axial load of Specimens ST33.7H50C and ST26.9H50C increased by about $15.7 \%$ and $14.7 \%$, respectively. Also, as the wall thickness of longitudinal steel tubes increased from $1.5 \mathrm{~mm}$ to $3.0 \mathrm{~mm}$, the maximum axial load of the SCC columns reinforced with ST33.7 steel tubes increased by about $13.8 \%$, whereas the maximum axial load of the SCC columns 
reinforced with ST26.9 steel tubes increased by about $8.4 \%$. However, the ductility of SCC columns reinforced with steel tubes was not significantly influenced by the increase in the tensile strength and wall thickness of steel tube.

5. For the increase of the pitch of steel helices from 40 to $100 \mathrm{~mm}$ in the SCC columns reinforced with ST26.9 steel tubes, the maximum axial load decreased by $10.3 \%$. Whereas increasing the pitch of steel helices from 40 to $100 \mathrm{~mm}$ in the SCC Colum reinforced with ST33.7 steel tubes, the maximum axial load decreased by $6.9 \%$. $y d_{t}$ ratio of the ST26.9 steel tube was $25 \%$ higher than the $s / d_{t}$ ratio of the ST33.7ste tube when the pitch of steel helix was $100 \mathrm{~mm}$.

6. For the increase of the pitch of steel helices $100 \mathrm{~mm}$ in the SCC columns reinforced with ST26.9 steel tubes, the ductility decreased by $40 \%$. Whereas increasing the pitch of steel helices from 40 to $100 \mathrm{~mm}$ SCC columns reinforced with ST33.7 steel tubes, the ductility decreased by $37 \%$.

\section{Acknowledgments}

The authors thank the Uyiyesty of Wollongong, Australia and technical officers at the High Bay Laboratory, esp CiallyMr. Ritchie McLean, for their help in the experimental work of this study. Finall, the first author would like to acknowledge the Iraqi Government for the support of his wescholarship. 


\section{ACCEPTED MANUSCRIPT}

\section{Notation}

$A_{\text {core }} \quad=$ area of the concrete core confined by steel helix

$A_{\text {cover }}=$ area of unconfined concrete cover

$A_{s h} \quad=$ cross-sectional area of the steel helix

$A_{t} \quad=$ cross-sectional area of the steel tube

$A_{\text {tube }}=$ area of the confined concrete inside steel tubes

$D_{c} \quad=$ centre-to-centre diameter of the steel helix

$d_{t} \quad=$ outside diameter of the steel tube

$E_{c} \quad=$ modulus of elasticity of the concrete

$E_{s h} \quad=$ modulus of elasticity of the steel helix

$E_{\text {sec,c }}=$ confined secant modulus of elasticity of the oncrete

$E_{\text {sec,u }}=$ unconfined secant modulus of elast the concrete

$E_{t} \quad=$ modulus of elasticity of the sten ture

$P_{\text {axial }}=$ total axial load of specimens

$f_{c} \quad=$ unconfined concrete stres

$f_{c}^{\prime} \quad=28$-day cylinder colcrempressive strength

$f_{c c, \text { core }}=$ axial stress in confined concrete core

$f_{c c, t u b e}=$ axial stress tholongitudinal steel tubes

$f_{c c} \quad=$ confined condrete stress

$f_{c c}^{\prime}=$ peak swoss of confined concrete

$f_{c o}=$ unconfined concrete compressive strength which is equal to $\propto_{1}$ multiplied by $f_{c}^{\prime}$

$f_{l} \quad=\quad$ effective confining pressure of steel helix

$f_{l t} \quad=\quad$ effective confining pressure of the steel tube

$f_{t} \quad=$ stress of the steel tube in the linear elastic portion

$f_{t y} \quad=$ yield stress of the steel tube

$f_{y h}=$ yield stress of the steel helix 


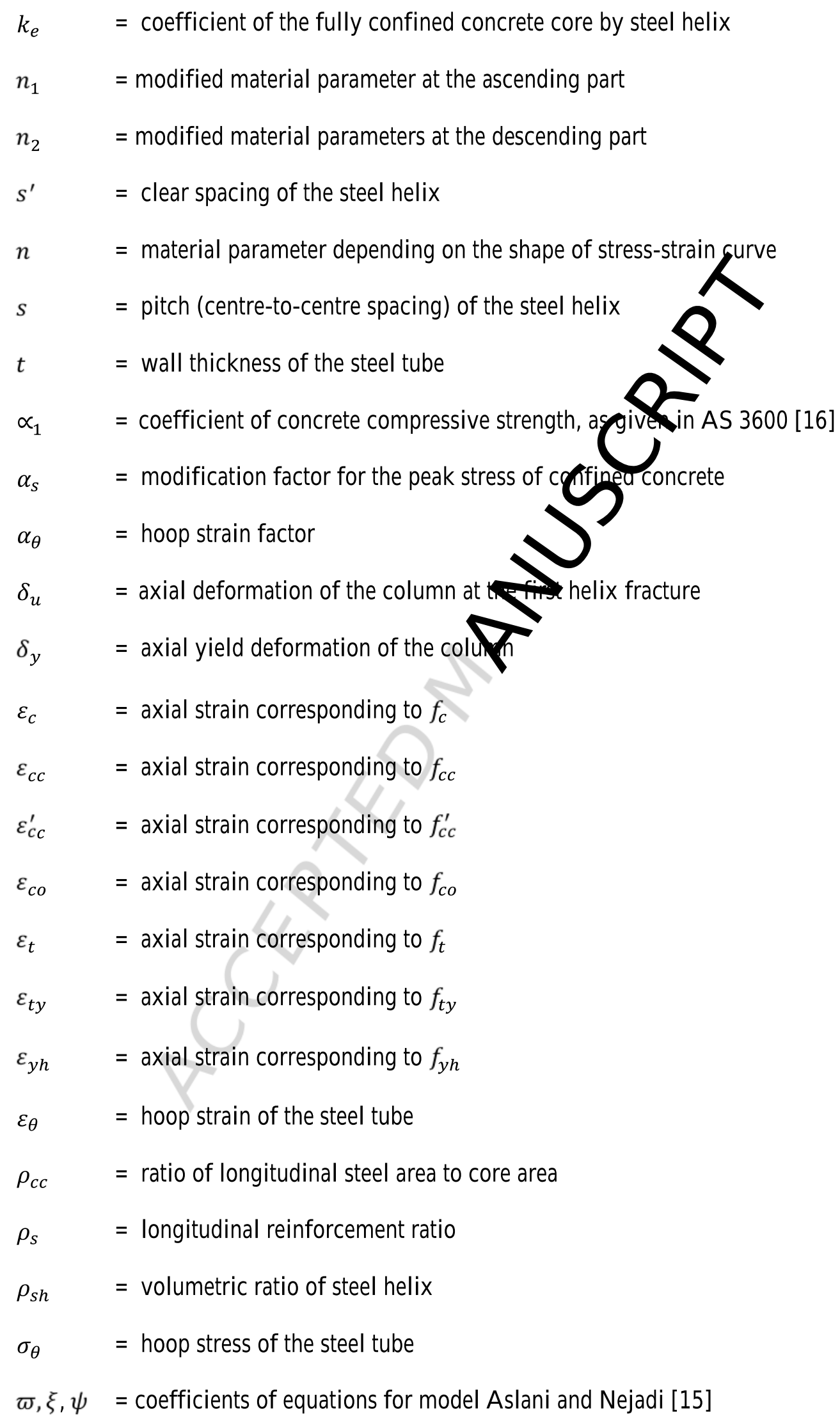




\section{Reference}

[1] Wang YC. Tests on slender composite columns. J Constr Steel Res 1999; 49(1):25-41.

[2] Susantha KAS, Ge H, Usami T. Uniaxial stress-strain relationship of concrete confined by various shaped steel tubes. Eng Struct 2001; 23(10):1331-1347.

[3] Hajjar JF. Composite steel and concrete structural systems for seismic engineering. J Constr Steel Res 2002; 58(5-8):703-723.

[4] Sakino K, Nakahara H, Morino S, Nishiyama I. Behavior of Ptrally loaded concretefilled steel-tube short columns. J Struct Eng ASCE 2004; 1304)

[5] Han L-H, Li W, Bjorhovde R. Developments and adva ced pplications of concrete-filled steel tubular (CFST) structures: members. J Constr Strefref2014; 100:211-228.

[6] Alhussainy F, Sheikh MN, Hadi MNS. Behavo of small diameter steel tubes under axial compression. Structures J. 2017; 11:155

[7] Oliveira, WLA, De Nardin S, El Debs_A El Debs MK. Influence of concrete strength and length/diameter on the axial gapacity of CFT columns. J Constr Steel Res 2009; 65(12):2103-2110.

[8] Moon J, Lehman D, Roeren Lee H. Strength of circular concrete-filled tubes with and without internal reinforceme under combined loading. J Struct Eng ASCE 2013; 139(12):112 .

[9] EFNARC. Sfeciffcation and guidelines for self-compacting concrete. The European Federation of 5 perel ist Construction Chemicals and Concrete Systems 2002.

[10] Paultre P, Khayat KH, Cusson D, Tremblay S. Structural performance of selfconsolidating concrete used in confined concrete columns. ACI Struct J 2005; 102(4):560568. 
[11] Alhussainy F, Hadi MNS, Sheikh MN. Behaviour of small-diameter self-compacting concrete-filled steel tubes. Mag Concr Res 2017; 1-11.

http://dx.doi.org/10.1680/jmacr.16.00531

[12] Lin C-H, Hwang, C-L, Lin S-P, Liu C-H. Self-consolidating concrete columns under concentric compression. ACI Struct J 2008; 105(4): 425-432.

[13] Lachemi M, Hossain KMA, Lambros VB. Axial load behavj of self-consolidating concrete-filled steel tube columns in construction and service Ses. ACl Struct J 2006; 103(1):38-47.

[14] Hadi MNS, Alhussainy F, Sheikh MN. Behavior of se f-conpacting concrete columns reinforced longitudinally with steel tubes. J Struct Ens 2017 ; 143(6):1-14.

[15] Aslani F, Nejadi S. Mechanical properties of sertional and self-compacting concrete: an analytical study. Const Build Mater 2012; 30.340.

[16] AS 3600-09. Concrete structure. Austratom Standard (AS), Sydney, 2009.

[17] Mander J B, Priestley MJN, Park Theoretical stress-strain model for confined concrete. J Struct Eng ASCE; 1988; 114(8) 1804-1826.

[18] Bing L, Park R, TanakahA. Stress-strain behavior of high-strength concrete confined by ultra-high- and normal-streng transverse reinforcements. ACI Struct J 2001; 98(3):395-406. [19] Wang X, Liu J Zhany S. Behavior of short circular tubed-reinforced-concrete columns subjected to ecce fric gompression. Eng Struct 2015; 105:77-86.

[20] Elremaily Azizinamini A. Behavior and strength of circular concrete-filled tube columns. J Constr Steel Res 2002; 58(12):1567-1591.

[21] Morino S, Tasuda K. Design and construction of concrete-filled steel tube column system in Japan. Earthq Eng and Eng Seismol 2002; 4(1):51-73. 


\section{ACCEPTED MANUSCRIPT}

[22] ASTM C1621/C1621M-14. Standard test method for passing ability of self-consolidating Concrete by J-Ring. West Conshohocken, PA, USA: American Society for Testing and Materials; 2014.

[23] ASTM C1611/C1611M-14. Standard test method for slump flow of self-consolidating concrete. West Conshohocken, PA, USA: American Society for Testing and Materials; 2014.

[24] ASTM C1610/C1610M-14. Standard test method for stati segregation of selfconsolidating concrete using column technique. West Conshohoren, PA, USA: American Society for Testing and Materials; 2014.

[25] ASTM C39/C39M-16. Standard test method for c(mprossive strength of cylindrical concrete specimens. West Conshohocken, PA, USA ADerican Society for Testing and Materials; 2016.

[26] ASTM A370-14. Standard test methodend definition for mechanical testing of steel products. West Conshohocken, PA, USA-A Aestan Society for Testing and Materials; 2014.

[27] AS 1391-07. Metallic materiatansile testing at ambient temperature. Australian Standard (AS), Sydney; 2007.

[28] Oliveira WLA, De NadMS, El Debs ALHC, El Debs MK. Evaluation of passive confinement in CFT colymns Constr Steel Res 2010; 66(4):487-495.

[29] ANSI/AISC 36/10. Secification for structural steel buildings. American Institute of Steel Constructio (AISC), Chicago; 2010.

[30] Abed F, Nyamaydeh M, Abdalla S. Experimental and numerical investigations of the compressive behavior of concrete filled steel tubes (CFSTs). J Constr Steel Res 2013; 80:429439.

[31] Ozbakkaloglu T, Saatcioglu M. Rectangular stress block for high-strength concrete. ACI Struct J 2004; 101(4):475-483. 


\section{ACCEPTED MANUSCRIPT}

[32] Pessiki S, Pieroni A. Axial load behavior of large scale spirally reinforced high strength concrete columns. ACI Struct J 1997; 94(3):304-313.

[33] Foster S], Attard MM. Experimental tests on eccentrically loaded high-strength concrete columns. ACI Struct J 1997; 94(3):295-302.

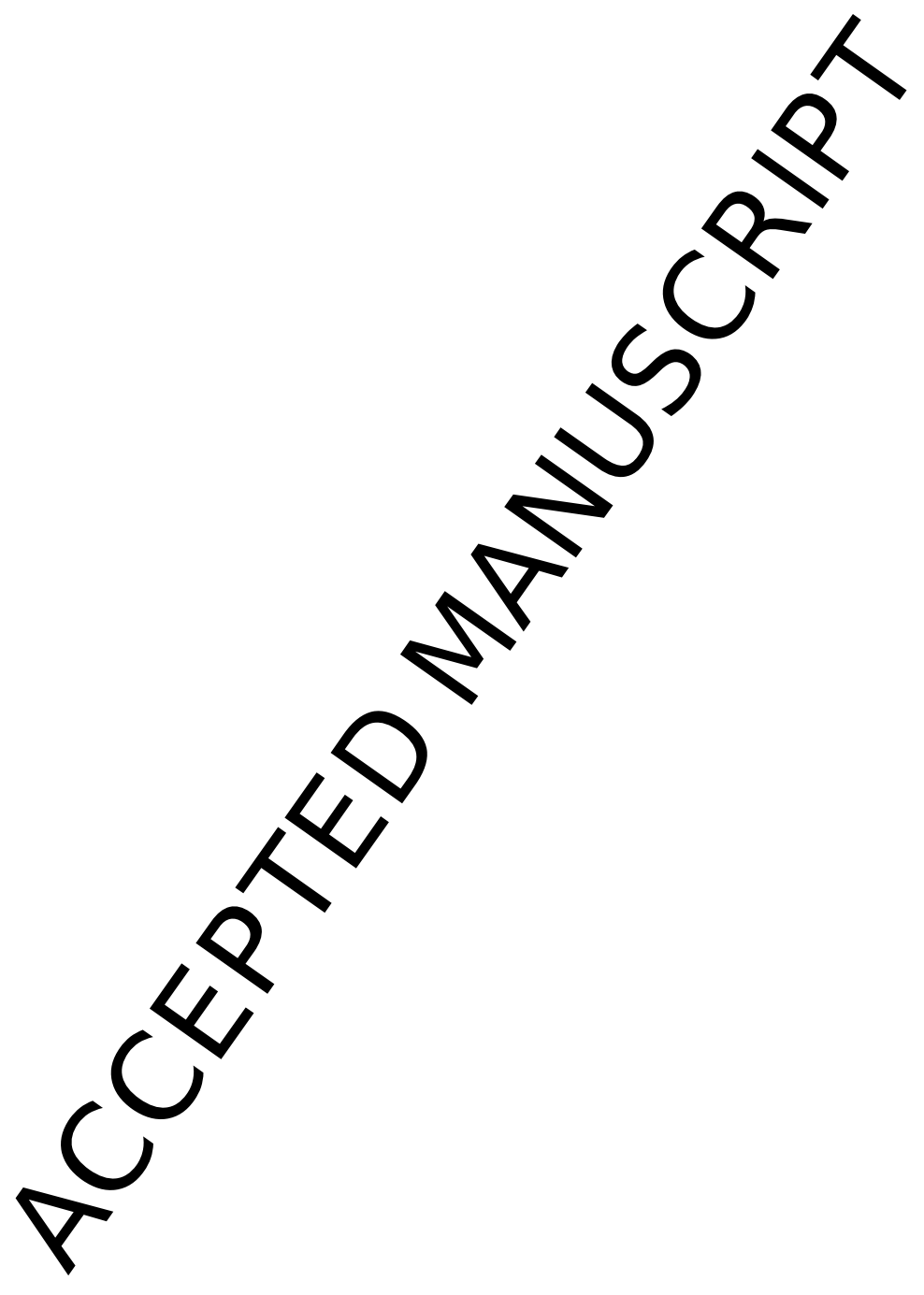




\section{List of tables:}

Table 1-Details and experimental results of four column specimens tested under concentric load

Table 2-The strains of the longitudinal and transverse reinforcements for the column specimens tested under concentric load

Table 3-The concrete enhancement factor for the types of confing concrete in the SCC columns

Table 4-Influence of the compressive strength of concrete ductility of columns

Table 5-Influence of the tensile strength of steel ture $h$ the maximum axial load and ductility of columns

Table 6-Influence of the wall thickness of ste maximum axial load and ductility of columns

Table 7-Influence of the pitch of steanelices on the maximum axial load and ductility of columns

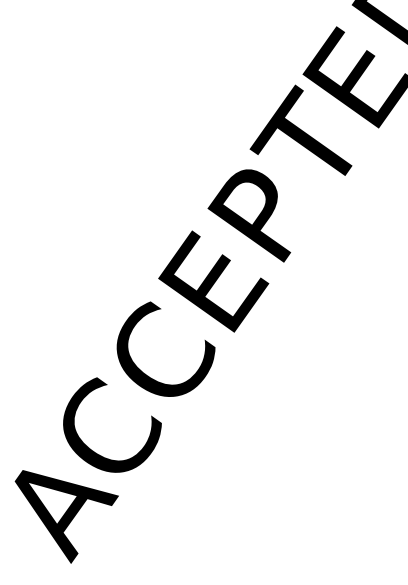




\section{List of figures:}

Fig. 1-Cross-sections of the self-compacting concrete columns: (a) column reinforced with steel bars; and (b) column reinforced with steel tubes

Fig. 2-Components in the columns reinforced with steel tubes: (a) axial stress-axial strain behaviour of each component; and (b) axial load-axial deformation behaviour of each component

Fig. 3-Positions of single element strain gauges and biaxial two ent strain gauges on the test specimens

Fig. 4-Comparison between analytical and experimental doal load-axial deformation behaviour of the tested specimens: (a) ST33.7H50C; ST 6.9H50C; (c) ST33.7H75C; and (d) $\mathrm{ST} 26.9 \mathrm{H} 75 \mathrm{C}$

Fig. 5-Influence of concrete strength on axia deaxal deformation behaviours of the SCC columns: (a) ST33.7H50C; and (b) ST26 ghror

Fig. 6-Influence of tensile strength gatel tubes on axial load-axial deformation behaviours of the SCC columns:

(a) ST33.7H 0 \% and (b

(b) ST26.9H50C

Fig. 7-Influence of wall thickneses of steel tubes on axial load-axial deformation behaviours of the SCC columns: (a) T3R ZHOC; and (b) ST26.9H50C

Fig. 8-Influence of Itch $\%$ steel helices on axial load-axial deformation behaviours of the SCC columns: (colymns reinforced with ST33.7 steel tubes; and (b) columns reinforced with ST26.9 steplyoues 


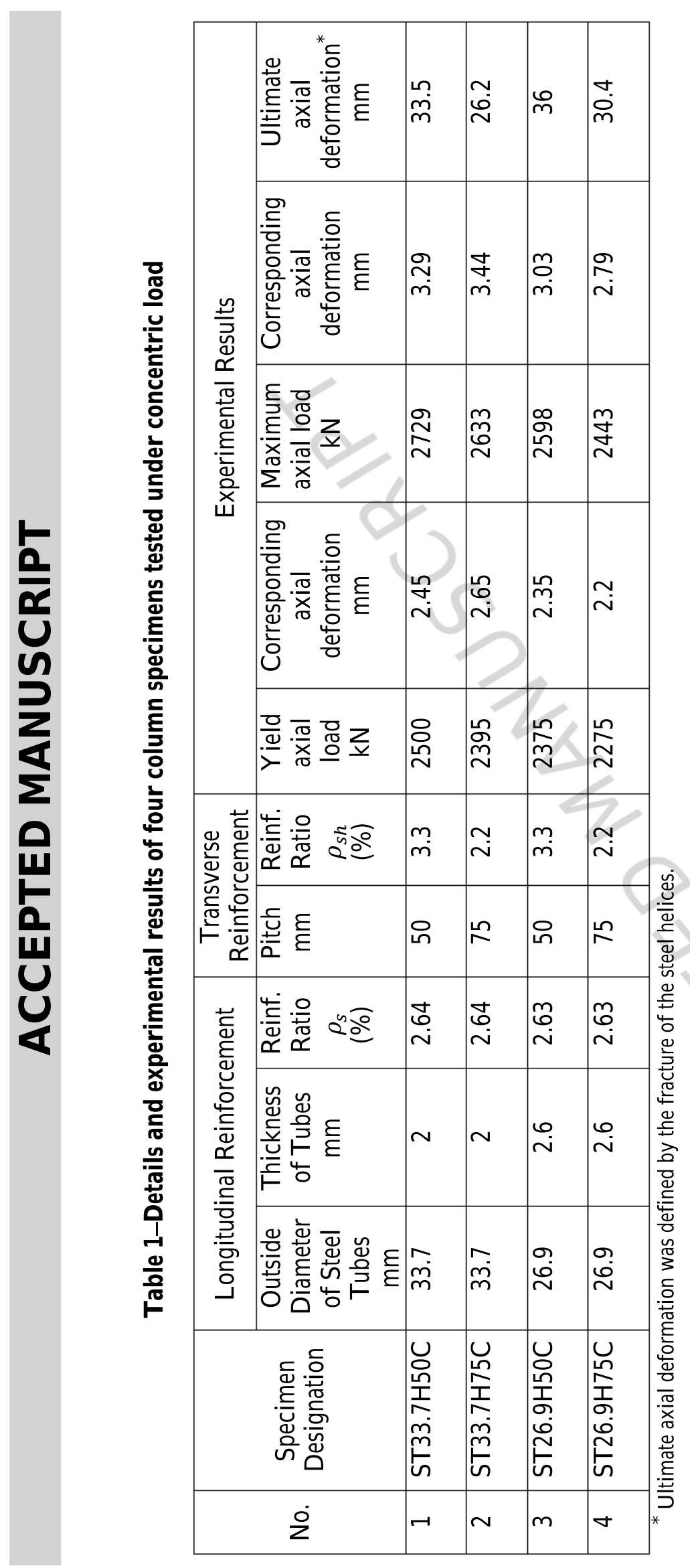




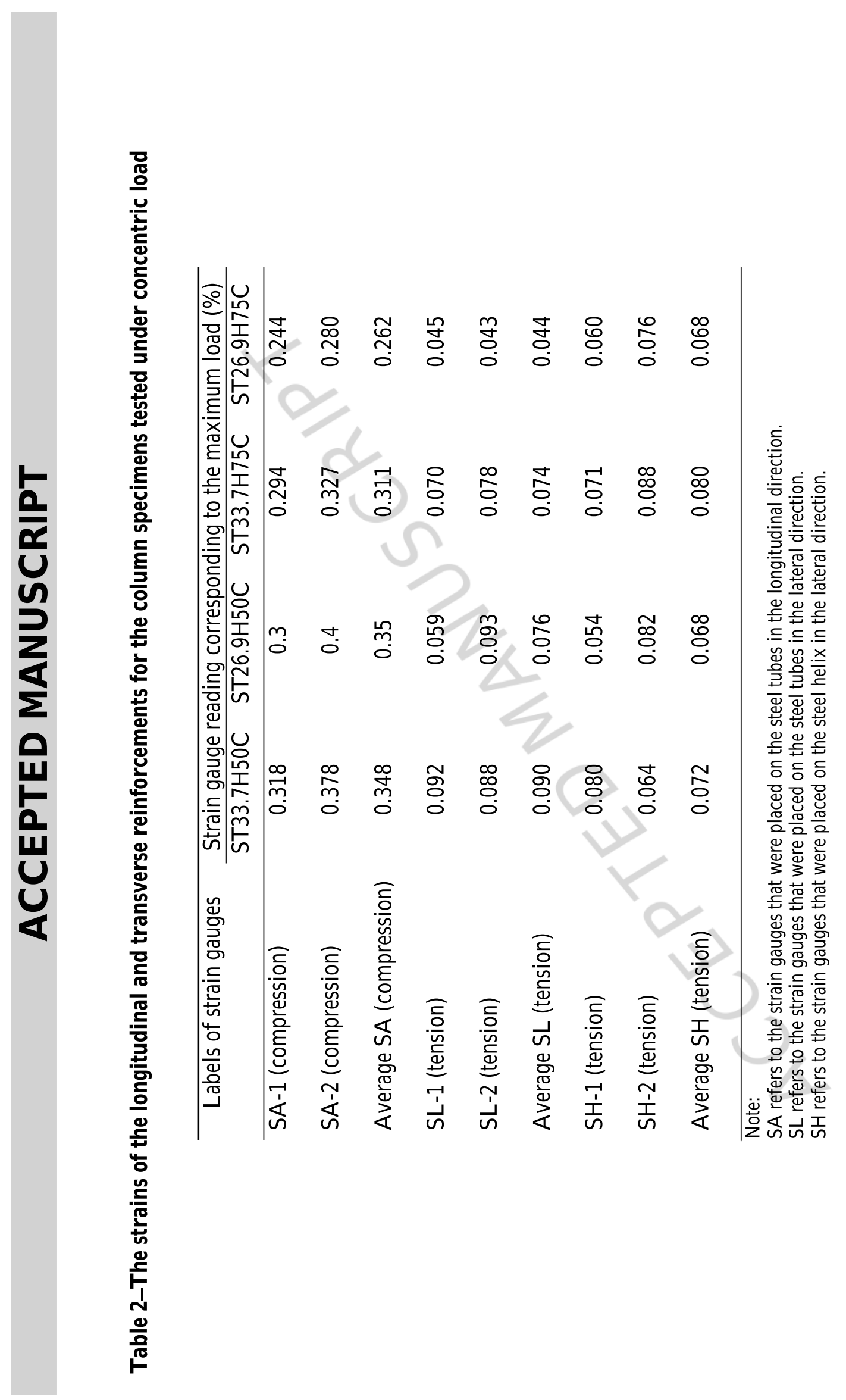




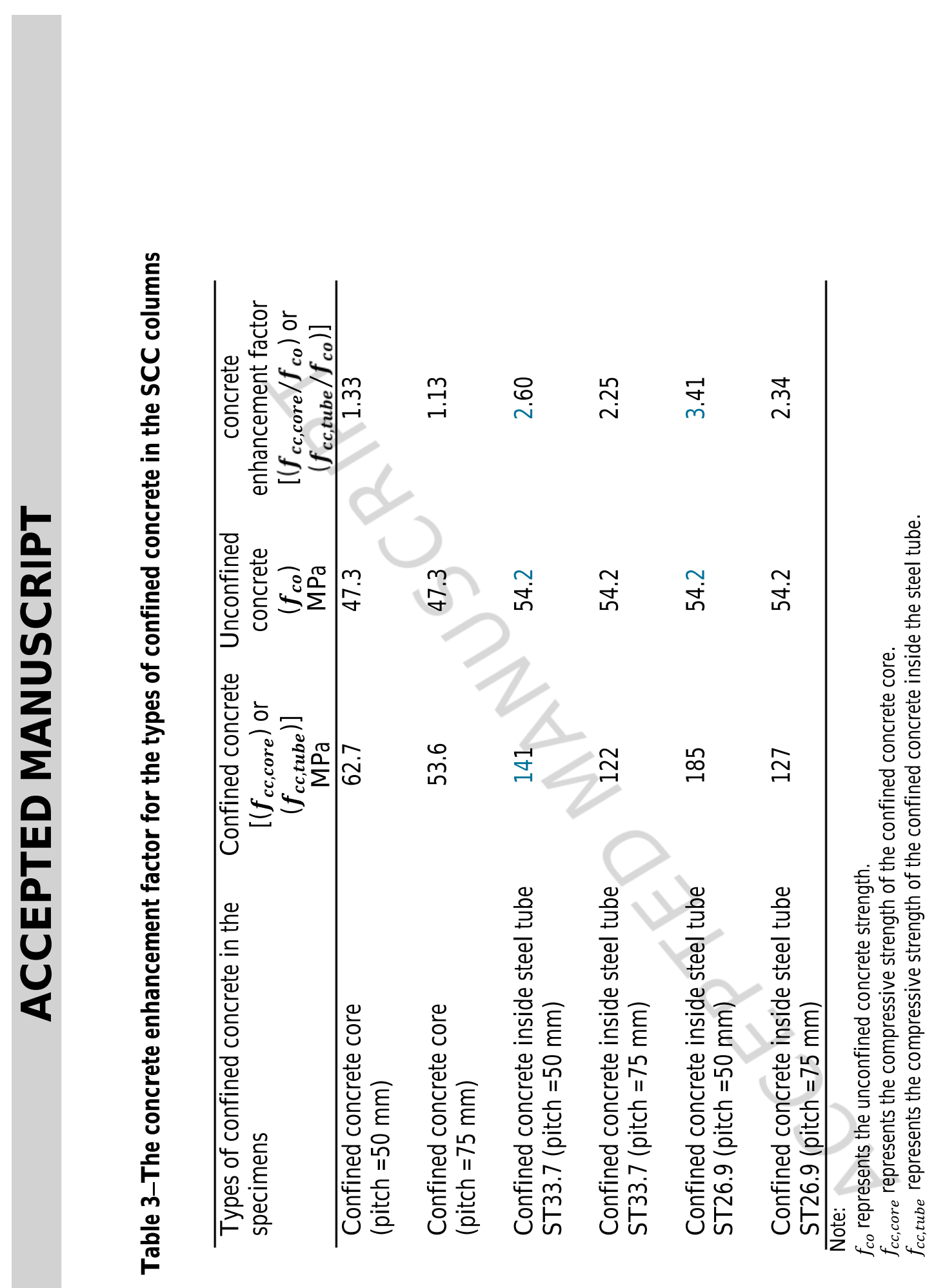




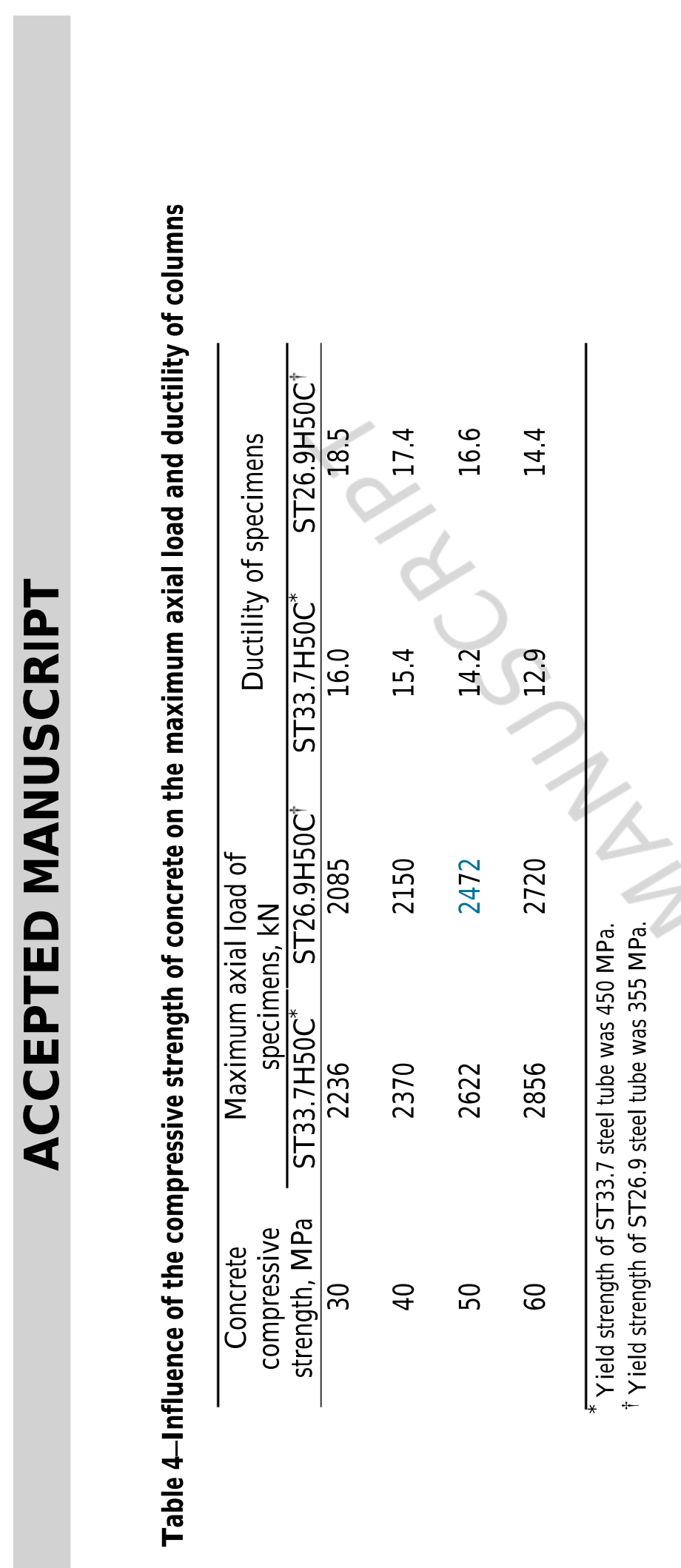




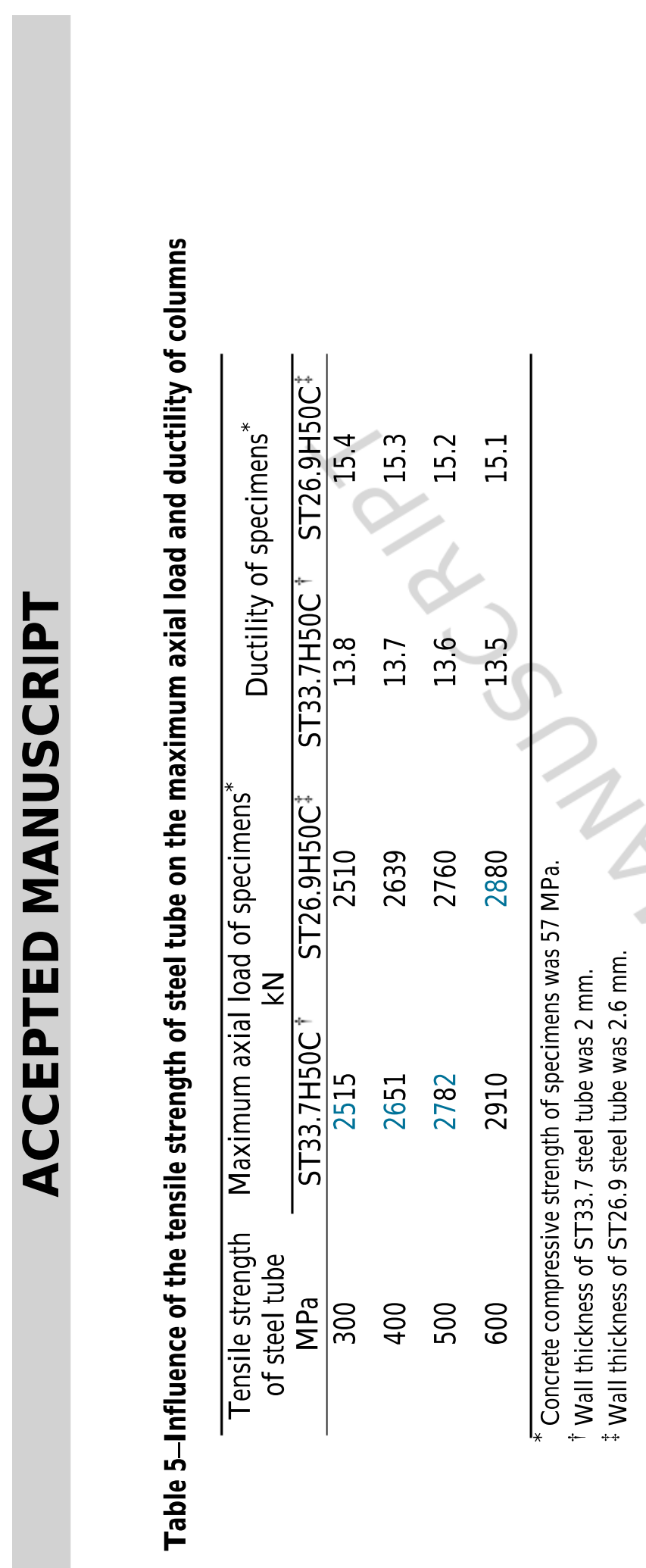




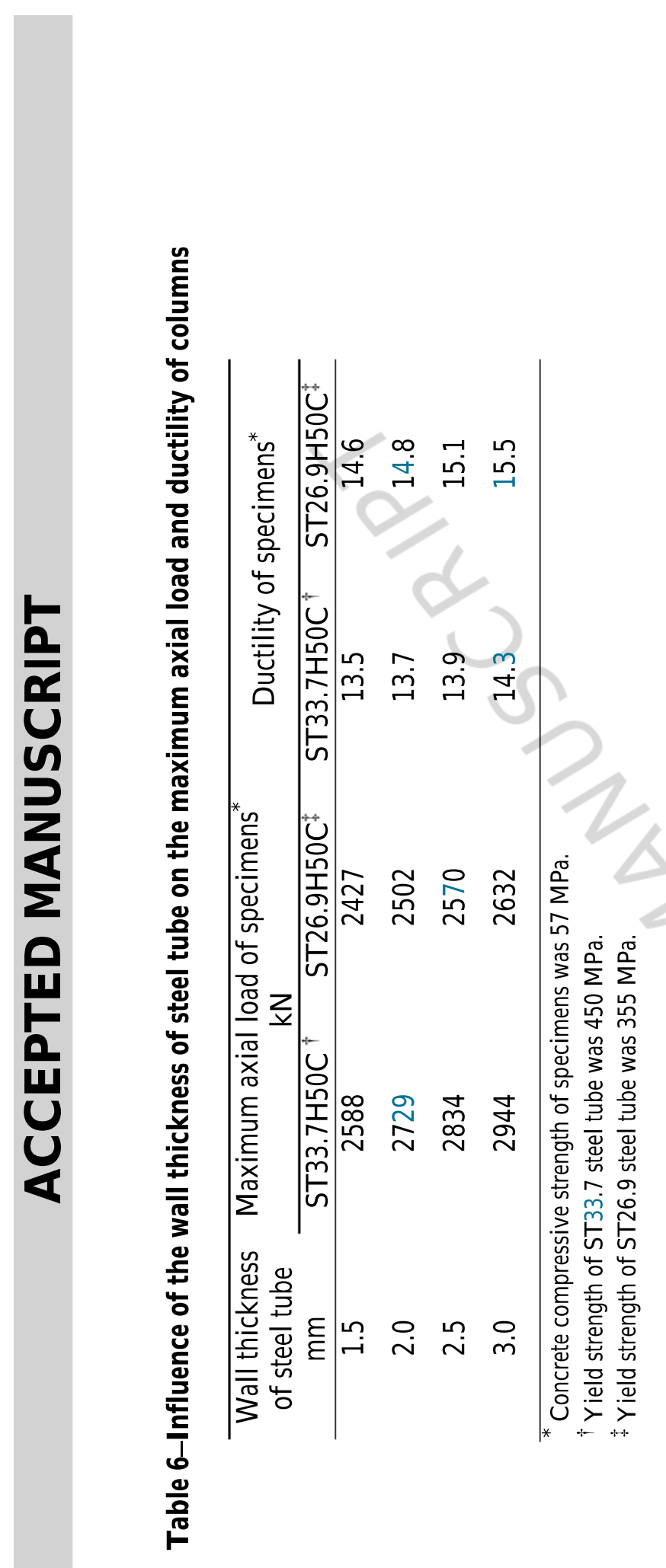




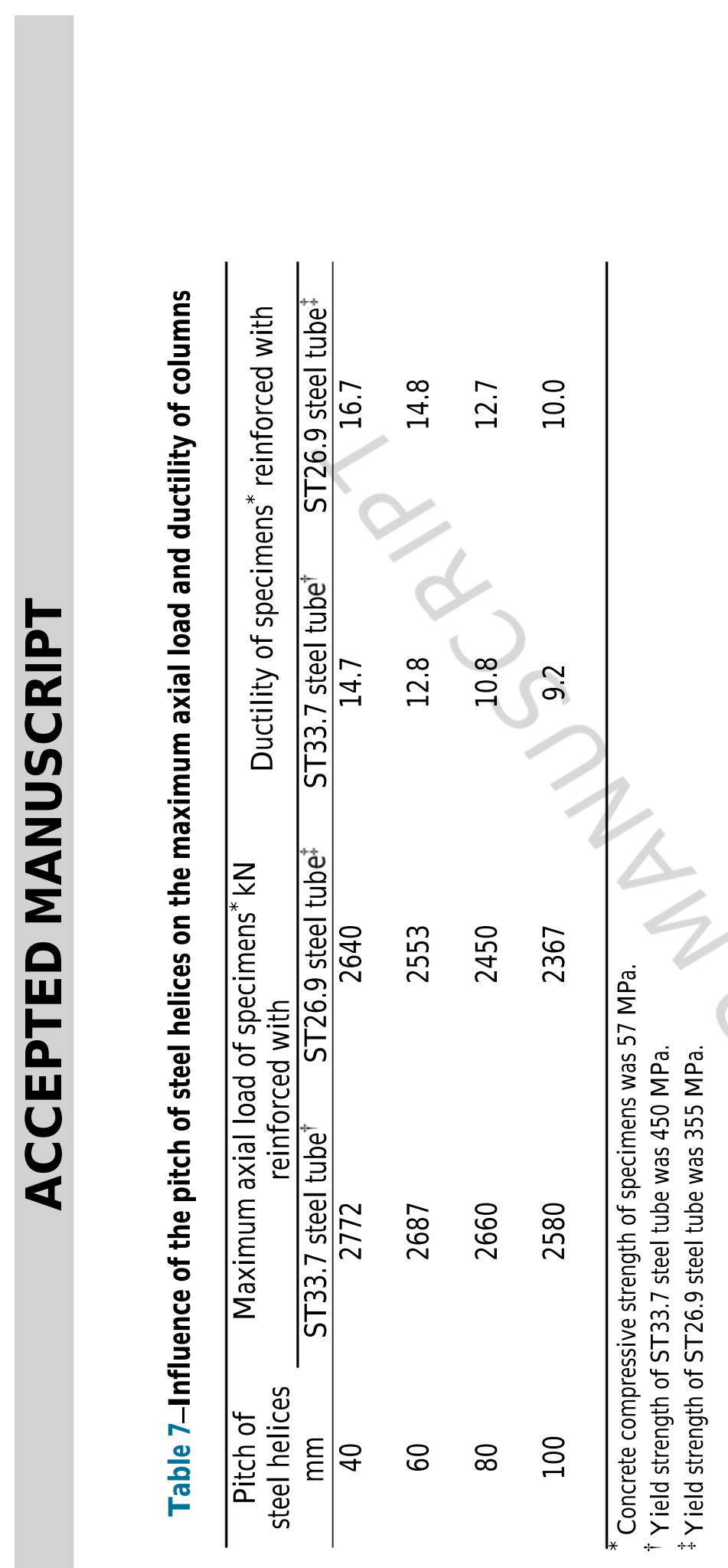




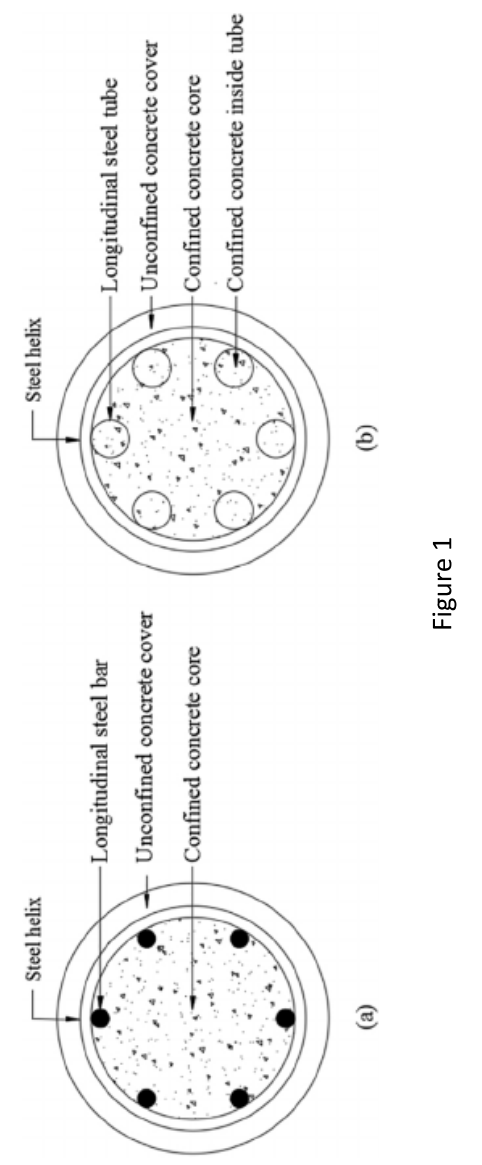




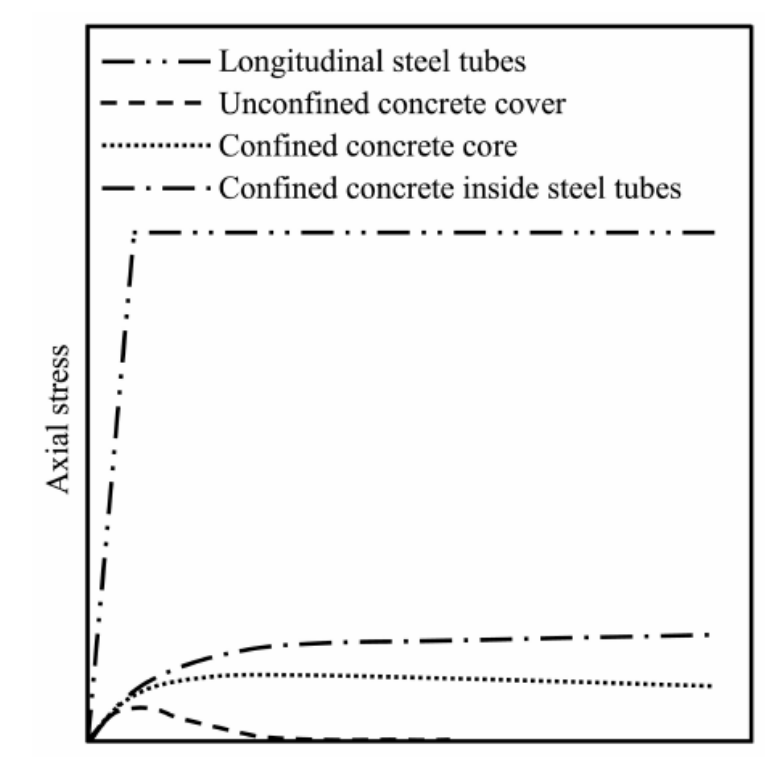

Axial strain

(a)

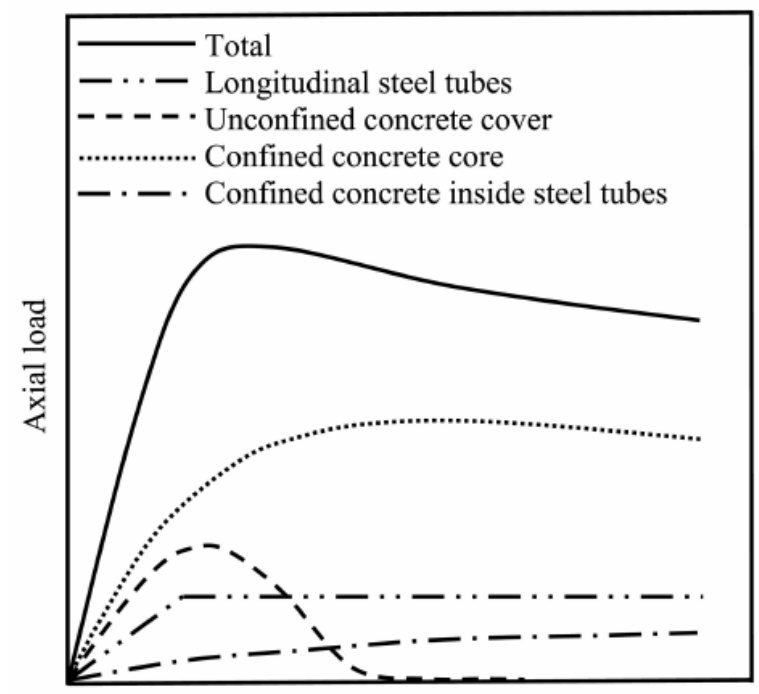

Axial deformation

(b)

Figure 2 


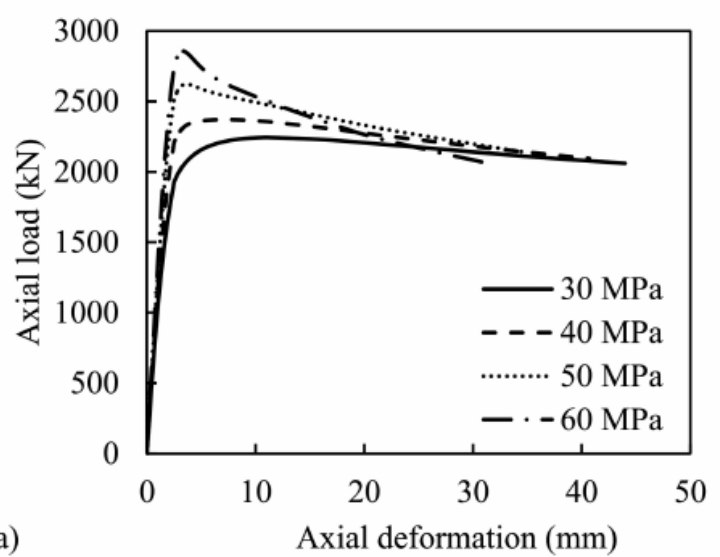

(a)

Axial deformation (mm)

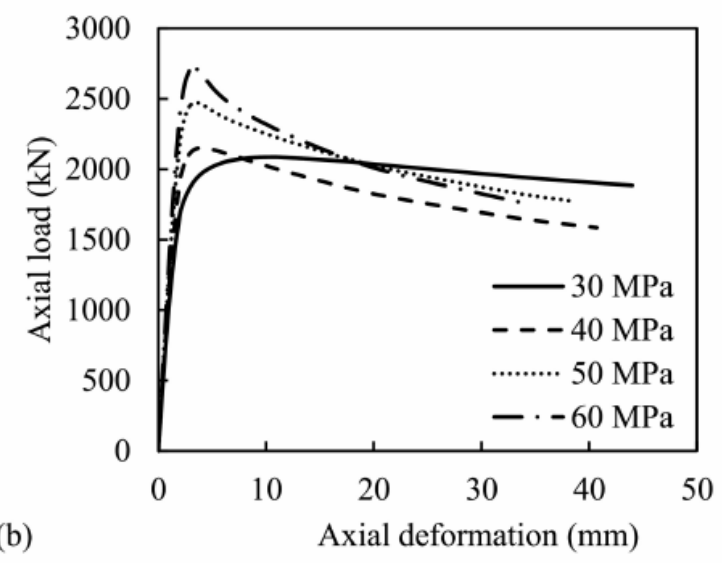

Figure 5 


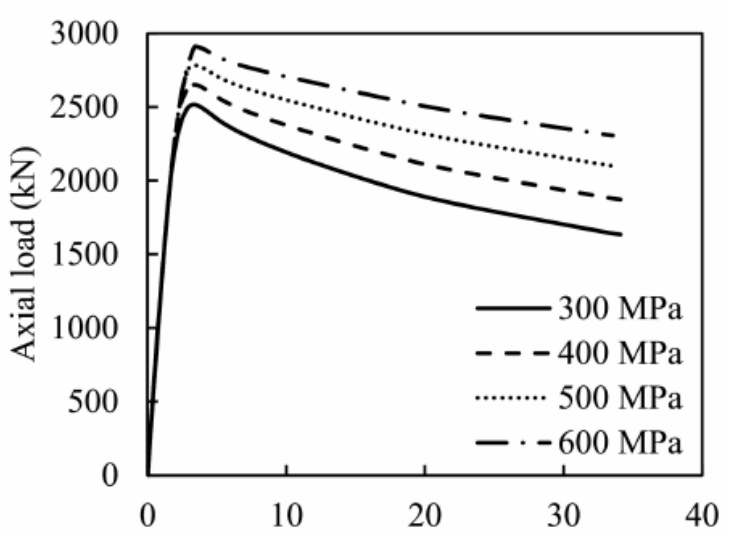

(a)

Axial deformation (mm)

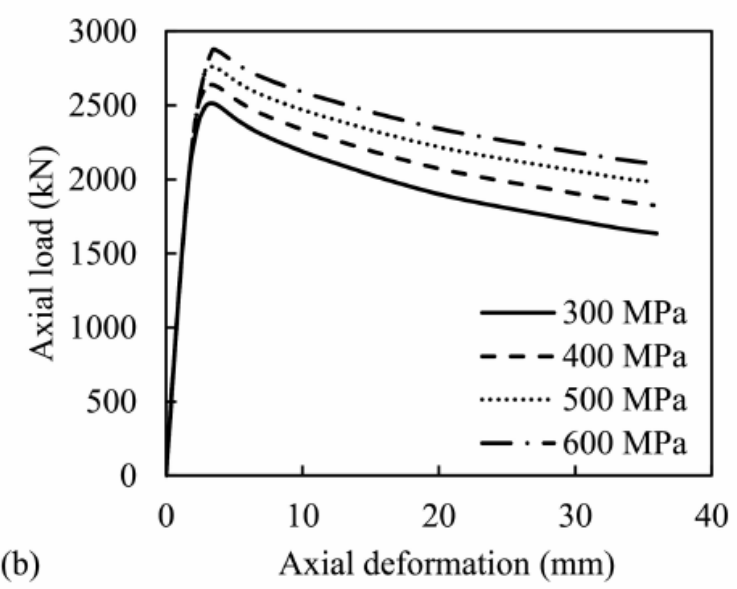

Figure 1 


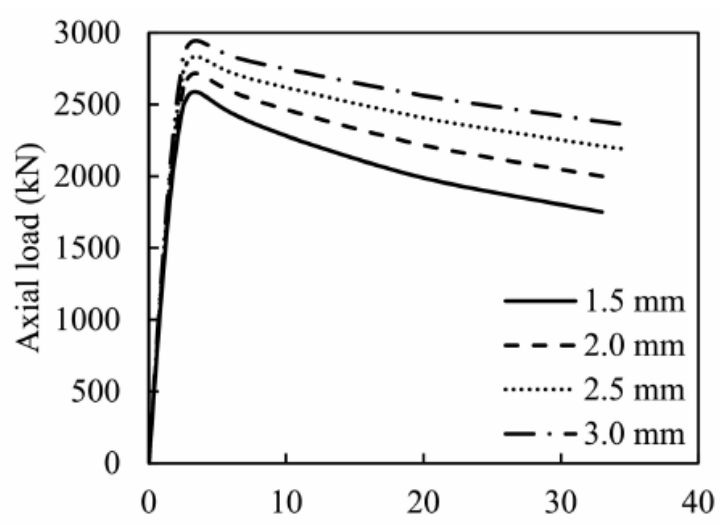

(a)

Axial deformation (mm)

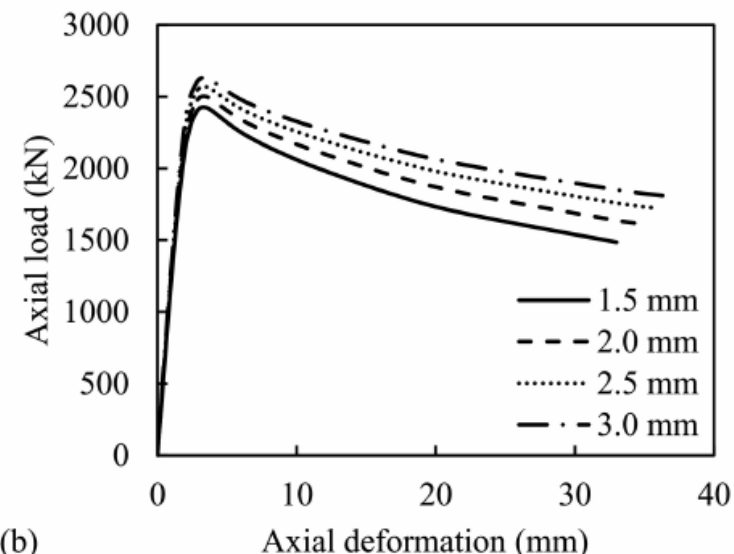

Figure 2 


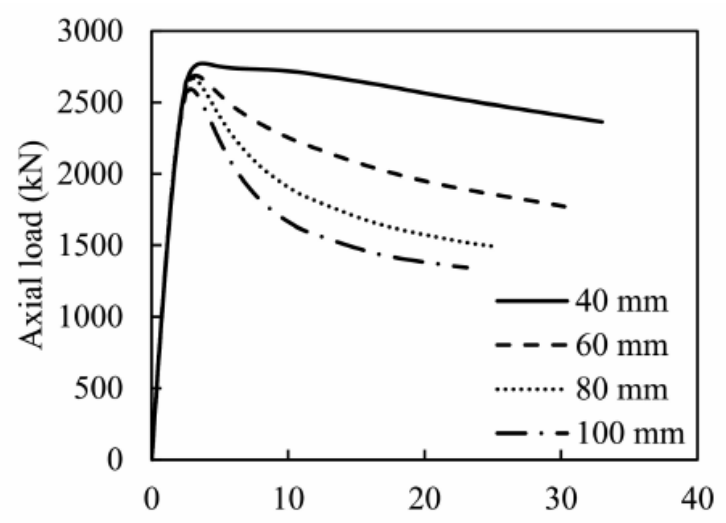

(a)

Axial deformation (mm)

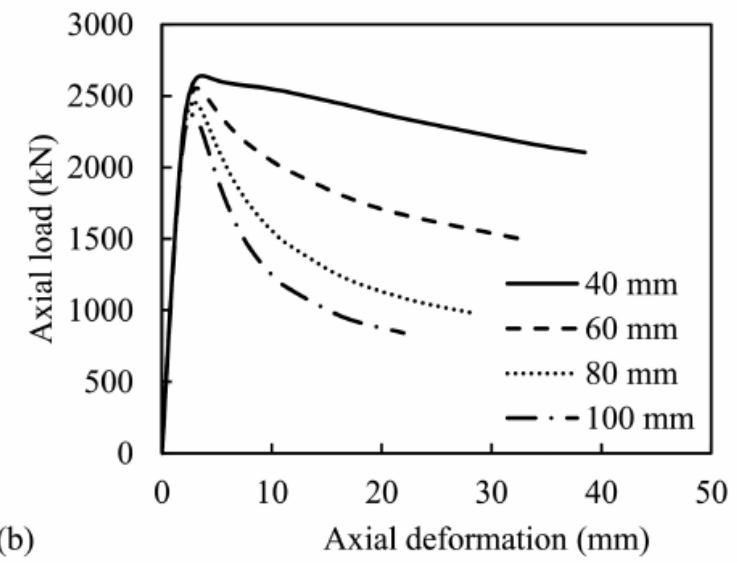

Figure 8 